\title{
TRANSFERENCIA DE SABERES: MODALIDADES E POSSIBILIDADES
}

\author{
Transference of knowledge: \\ modalities and possibilities \\ Helenice Rodrigues*
}

\begin{abstract}
RESUMO
Possibilitando o abandono de um quadro epistemológico da historiografia nacional, a teoria das "transferências culturais" abriu espaço para os estudos multilaterais, envolvendo os processos de inter-relações: intercâmbios, exportações, importações, apropriações, recepções de ideias, de modelos, de valores etc. Este vasto campo de pesquisa interdisciplinar revelou seu valor crítico e heurístico em diversas áreas das ciências humanas e sociais, quando confrontadas à problemática da mundialização do conhecimento, da interpenetração de modelos culturais e dos sistemas de referência.
\end{abstract}

Palavras-chave: transferências culturais; mediação; ciências humanas.

\begin{abstract}
By giving up an epistemological framework of national historiography, the theory of "cultural transfers" paved the way for multilateral studies, involving the processes of inter-relations: interchanges, exports, imports, appropriations, reception of ideas, of models, of values, etc. This broad field of interdisciplinary research revealed its critical and heuristic value in several areas of the human and social sciences facing the issues inherent to the globalization of knowledge, the interpenetration of cultural models and systems of reference.
\end{abstract}

Key-words: cultural transfers; mediation; human sciences.

* Professora associada na Universidade Federal do Paraná (UFPR). 
Se o objeto exílio limitou-se à abordagem, notadamente, da circulação de pessoas e de ideias, ele propiciou, de maneira simultânea, a apreensão de outras modalidades de deslocamento, de travessia e de cruzamento cultural ${ }^{1}$. Investigar os processos e os mecanismos de transposição, de apropriação, de readaptação de valores e de modos de pensar estrangeiros que eu proponho, em seguida, exigiu a apreensão de uma "verdadeira" área de pesquisa das ciências humanas: as "transferências culturais".

"Transmitidos pelos indivíduos e [pelos] grupos que atravessam a fronteira, as ideias, os livros, os valores transportados se transformam"2, em razão mesmo das mudanças de conjunturas da estrutura que os recebe. Assim, quando um texto científico é transposto de um espaço cultural (intelectual e linguístico) para um outro espaço nacional, inevitavelmente, sua significação, ligada a sua historicidade e a sua temporalidade, se modifica. Ora, de um país para o outro os textos circulam sem seu devido contexto de produção. Essa separação das produções culturais de seu sistema de referências, em relação às quais as ideias se definem, não resiste ao que Pierre Bourdieu designa por "décontextualisation" e por "dé-nationalisation"3.

Como, então, apreender os mecanismos da passagem ou da transposição de uma ideia, de um valor, de um modelo intelectual de um país a um outro? Como proceder à análise das apropriações de ideias vindas de outros contextos culturais?

Confrontado, atualmente, à conjuntura da mundialização do conhecimento, ao retorno da hermenêutica e à problemática das "transferências culturais"4, um número significativo de estudos em língua, em literatura e em ciências humanas ${ }^{5}$ voltou-se à análise das relações culturais recíprocas.

1 Cf. RODRIGUES, Helenice. "O exílio dos intelectuais e os intelectuais exilados". In: RODRIGUES, Helenice; KOHLER, Heliane (Orgs.). Travessias e cruzamentos culturais: a mobilidade em questão. Rio de Janeiro: Edição FGV, 2008.

2 ESPAGNE, Michel. Les transferts culturels franco-allemands. Paris: PUF, 1999, p. 27. Cf. ESPAGNE, Michel; WERNER, Michaël. La construction d'une référence allemande en France 1750/1914: Genèse et histoires culturelles. Annales ESC, juillet - août 1987. Ver também Transferts. Les relations interculturelles dans l'espace franco-allemand. Paris: Éditions Recherche sur les Civilisations, 1988, p. 27.

3 BOURDIEU, Pierre. Les conditions sociales de la circulation internationale des idées. Actes de la recherche en sciences sociales, n. 145, décembre 2002, p. 3.

4 Tais como os praticados na França por Michel Espagne, por Michaël Werner e por HansJürgen Lüsebrink na Alemanha.

5 A criação de grupos de pesquisas em diferentes países (europeus e nos Estados Unidos) e a realização de colóquios internacionais, nesta última década, atesta a importância deste objeto. 
Assim, o estudo das imbricações interculturais abriu espaço ao enfoque do transnacional, do transversal e do cruzamento cultural. Permitindo ultrapassar o quadro nacional do pensamento, as "transferências culturais" acentuaram as inter-relações e suas mestiçagens, rompendo, desse modo, com os limitados estudos sobre as relações ou as influências culturais, incapazes, segundo Michel Espagne, de "confrontar os elementos exteriores à tradição nacional"’.

Sem dúvida, o fenômeno da globalização conduziu as ciências humanas a estender seus eixos de investigação (até então limitados às esferas nacionais) a outros espaços culturais. Um exemplo significativo encontra-se na prática da chamada "história global", em vigência nos Estados Unidos desde meados dos anos 1980 (“connected history”) e, na França, mais recentemente ("histoire croisée"), que busca ultrapassar a pluralidade das histórias particulares ${ }^{7}$. Rompendo fronteiras territoriais e disciplinares, estas novas áreas das ciências humanas passaram a incorporar a dimensão do global, do interativo e da pluralidade ${ }^{8}$.

Com efeito, as análises das "transferências culturais", inauguradas através dos estudos literários e filológicos sobre a França e a Alemanha (no século XIX) ${ }^{9}$, acentuaram os mecanismos de transmissão, os processos de importação (mas também de exportação), as análises de intercâmbios, de interações (entre países e modelos ocidentais). Marcada, num primeiro momento, pelas abordagens bilaterais ou comparadas, a teoria das transferências culturais (que é também uma metodologia) não tardou a privilegiar as análises multilaterais e os enfoques "conectados", ou cruzados, para apreender o conjunto das relações complexas: os intercâmbios, as seleções, as transformações, mas também as formas de resistência e de rejeição.

Como atuam os "agentes" e/ou os mediadores dessas transferências culturais? De que maneira essas transposições se operam, em termos interculturais? Como analisar as etapas de apropriação, de readaptação ou de imitação?

6 ESPAGNE, Michel. Les transferts culturels franco-allémands. Paris: PUF, 1999, p. 267.

7 TESTOT, Laurent (Org.). Histoire globale - un nouveau regard sur le monde. Paris: Éditions Sciences Humaines, 2008.

8 RODRIGUES, Helenice. A história global: abordagens comparativas e cruzadas. In: SIMPÓSIO NACIONAL DE HISTÓRIA, 25. Anais do Simpósio, 2009.

9 Explicitadas mais abaixo. 
Visando entender os mecanismos de transmissão do conhecimento - os processos de importação e de exportação - e estudar as imbricações interculturais entre países, as "transferências culturais" substituíram as antigas análises das relações ou das influências pela abordagem das imbricações e de seus hibridismos (cruzamentos de gêneros diferentes). Nesse sentido, essa nova área de pesquisa preencheu um déficit teórico nas áreas culturais e nas literaturas comparadas, quando confrontadas a elementos exteriores à tradição naciona $1^{10}$. Se, segundo seus teóricos, as abordagens das relações e das influências culturais se limitavam à análise do espaço nacional, os estudos das imbricações e das apropriações dimensionaram os "lugares da memória estrangeira".

A noção de "transferência cultural" remeteu, portanto, às pesquisas empíricas (quantitativas e qualitativas) e a uma orientação metodológica, utilizadas de maneira diversa, pelas ciências sociais e humanas. Embora reconhecendo o valor crítico e heurístico do conceito das "transferências culturais", para o estudo das áreas culturais (particularmente para a história intelectual) e literárias não se pode negar certas dificuldades na aplicação empírica desse modelo teórico.

Sem pretender aprofundar esse objeto complexo, pouco investigado no Brasil ${ }^{11}$, tentarei esboçar alguns dos seus procedimentos e propor pistas para possíveis estudos empíricos e críticos da história intelectual.

\section{A teoria das transferências culturais: o discurso de um método}

Conotando, ao mesmo tempo, "fluxo econômico, mobilidade de população e um dos momentos da cura psicanalítica", a expressão "transferências culturais" passou a designar pesquisas das ciências humanas nas áreas de intercâmbios culturais. Forjado em meados dos anos 1980, por

10 ESPAGNE, Michel. Op. cit., p. 296.

11 Os estudos em literatura comparada constituem exceções. Cf. BERND, Zilá (Org.). Americanidade e transferências culturais. Porto Alegre: Editora Movimento, 2003. 
Michel Espagne e Michaël Werner, para o estudo das relações literárias e intelectuais entre a França e a Alemanha a partir do século XVIII, esse conceito serviu para significar, inicialmente, os empréstimos (de ideias, de discursos, de valores, de objetos etc.), as interações entre culturas e sociedades (ou frações e grupos no interior de uma sociedade). Baseada, num primeiro momento, em perspectivas comparativas, essa pesquisa evoluiu em direção à ideia de conexões e cruzamentos. Revelando-se de grande operacionalidade para a análise de diferentes domínios: história cultural, sistemas religiosos, instituições políticas e jurídicas, história intelectual e política, estudos literários, a teoria e o método das "transferências culturais" estenderam-se aos Estados Unidos e à Europa, alcançando diferentes áreas da história (antiga, medieval, moderna, contemporânea).

Fundamentado na ideia de empréstimo, de importação, de hibridismo, de reapropriação, de tradução, de transformação, entre sociedades e culturas, esse conceito interdisciplinar implica em uma concepção de movimento e de circulação de objetos, populações, indivíduos, ideias, crenças entre dois ou mais espaços culturais (estados, nações, grupos étnicos, áreas culturais e religiosas) ${ }^{12}$. As "transferências culturais" reforçam, portanto, a noção de deslocamento, de circulação e de mobilidade de pessoas, de ideias, de objetos e de valores. Trabalhado, recentemente, pela história antiga (o mundo helenístico e romano, principalmente ${ }^{13}$ ), esse conceito evidencia noções de aculturação, helenismo, romanização etc. Neles, os objetos analisados podem ser os livros, as peças de arte, os sistemas de pensamento. Tenta-se entender os mecanismos de aculturação, mas, também, as rejeições às culturas, as práticas culturais, o fenômeno das recepções e das traduções.

Portanto, a diversidade das pesquisas e suas ambições totalizantes obrigam seus utilizadores a se questionarem sobre a própria acepção do termo cultural. Seu emprego, bastante amplo, pode dar margem a imprecisões. Como bem observa Béatrice Joyeux, "uma definição tão vasta [como esta das inter-relações culturais] justifica a aplicação da teoria das transferências a qualquer época e a todos os conjuntos culturais" ${ }^{14}$. Consequentemente, cabe

12 Cf. MOATTI, Claudia. La mobilité des personnes en Méditerranée - de l'antiquité à l'époque moderne. Rome: École Française de Rome, 2004.

13 Disponível em: $<\mathrm{http}: / /$ pheacie.univ-paris $1 . f r /$ page $\% 20 \mathrm{~d} \% 27$ accueil.htm $>$.

14 JOYEUX, Béatrice. Les transferts culturels, un discours de la méthode (bilan historiographique, perspectives d'application). Hypothèses. Paris: Presse Universitaire de la Sorbonne, 2002. 
ao pesquisador a definição, a delimitação precisa dos conjuntos culturais e a interrogação das condições de possibilidades da utilização deste método.

Segundo Michel Espagne, é fundamental para o estudo das "transferências culturais" a dimensão intercultural dos conceitos que elas analisam, ou seja, as próprias transferências, que são também fenômenos de criação e de deslocamento semântico ${ }^{15}$.

Nesses últimos anos, novos campos de investigação se abriram para o estudo das transferências culturais, como, por exemplo, a história antropológica sobre a mestiçagem como pensamento da alteridade e da relação ao Outro. Na realidade, essas pesquisas são indissociáveis da relação da dominação histórica que a Europa estabeleceu com outras culturas e se inscrevem nos chamados post-colonial studies ${ }^{16}$.

A noção de transferências culturais pressupõe o processo de relação entre dois "sistemas autônomos e assimétricos". Segundo seus teóricos, existem vários modelos (disciplinares, metodológicos) para a análise da passagem de uma cultura a outra. Trata-se, inicialmente, da análise da conjuntura e, em seguida, da utilização da hermenêutica. Se a história política, cultural e intelectual permite detectar os contextos de produção, por sua vez, o conhecimento da língua e da tradução possibilita levar em conta o processo de migração e de recepção cultural.

Sabe-se que nesse processo de tradução, ou seja, de reapropriação de um texto, ocorrem transformações e deformações. Assim, quando um livro, uma teoria, uma tendência estética, ultrapassam as fronteiras (espaciais, temporais e virtuais) entre espaços culturais distintos, sua significação, subtendida por seu contexto (intelectual e histórico), modifica-se pelo simples fato da defasagem (em geral, temporal) da transferência. Logo, os objetos de análise são os mais distintos possíveis: os processos de seleção, de mediação, de recepção, de mestiçagem, de tradução, de migração, de intercâmbio etc.

15 ESPAGNE, Michel. Op. cit., p. 5.

16 TURGEON, Laurier; DELAGE, Denys. Transferts culturels et métissages Amérique/ Europe, XVI-XX siècle. Paris: Presse de l'Université de Laval, 1996. 


\section{Procedimentos de análise: questionamentos}

As pesquisas atuais privilegiam grades de leitura diversas. A primeira abordagem inscreve-se, particularmente, no aspecto linguístico (via literatura comparada) e interessa-se, particularmente, pela tradução (mas, igualmente, pela transmissão e recepção); a segunda abordagem, de ordem sociológica e intelectual, volta-se para os processos de produção, de difusão e de apropriação por parte de agentes; uma terceira, de ordem econômica, preocupa-se com a análise dos mercados e das concorrências ${ }^{17}$.

Segundo Michel Espagne, a teoria da comunicação fornece o mais simples e clássico estudo sobre a emissão, a difusão e a recepção. Em geral, os pesquisadores inspiram-se nesta teoria que, na opinião dos mesmos, possibilita melhor entender todo o processo de transferência. Partindo dos discursos de origem, passando pelos veículos de transmissão (mídias e os intermediários culturais) e pelas formas de tradução, de reescrita e de transposição, tenta-se apreender o processo de recepção, desvendado por intermédio das transformações ${ }^{18}$.

Uma entidade cultural emite uma mensagem [...]. [Ela] é transmitida a um receptor que a decodifica. Mas o emissor e o receptor não se situam em um espaço vazio, eles são submetidos à observação de terceiros, algumas vezes designados na [própria] mensagem que leva em conta a presença deles. Além do mais, a mensagem transmitida deve ser traduzida a partir do código de referências do sistema de emissão para o do sistema de recepção. Esta apropriação semântica transforma profundamente o objeto transposto de um sistema a um outro [sistema $]^{19}$.

Em outras palavras, toda mensagem transmitida, seja dentro ou fora de um espaço cultural, é objeto de uma reinterpretação. Assim, em todo processo de decodificação, a questão hermenêutica determina, obviamente, $o$

17 Cf. JOYEUX, Béatrice. Les transferts culturels, un discours de la méthode (bilan historiographique, perspectives d'application). Hypothèses. Paris: Presses Universitaires de la Sorbonne, 2002.

18 Cf. LÜSEBRINK, Hans-Jürgen; REICHARDT, Rolf. Histoire des concepts et transferts culturels, 1770-1815. Note sur une recherche. Genèses, v. 14, janvier 1994.

19 ESPAGNE, Michel. Op. cit., p. 20. 
início de todo o processo de apropriação. Por um lado, "trata-se de interpretar um objeto estrangeiro, de integrá-lo em um novo sistema de referências que, antes de tudo, corresponde a novas referências linguísticas de traduzir" ${ }^{20}$. $\mathrm{Na}$ maioria das vezes, o objeto importado dá margem a uma nova interpretação, seja por parte de um indivíduo, seja por parte de um grupo (por exemplo, de uma revista, de uma universidade) que assimila este objeto.

No entanto, a interpretação nem sempre corresponde a uma primeira apropriação de um objeto importado. É possível que o procedimento hermenêutico demonstre uma reinterpretação das interpretações anteriores. Um exemplo significativo de readaptações de ideias pode ser encontrado na apropriação da filosofia alemã na França, no século XIX. Sofrendo modalidades diversas de traduções, de apropriações e de transformações, a filosofia na França constitui "uma entidade mista, híbrida" 2 , tal a sua imbricação com a alemã, constata Michel Espagne. Entre os mediadores desta transferência filosófica encontram-se as instituições universitárias, as editoras especializadas, os atores individuais (escritores franceses e alemães), os emigrantes alemães etc.

Assim, a filosofia kantiana, no espaço cultural francês, passou por contínuos processos de apropriação. Redigidos dentro de uma conjuntura política e ideológica precisa, os textos sobre Kant diferiram de perspectivas. Ao lado de um Kant jacobino, racionalista, introduzido pelos emigrantes alemães, em Paris, no final da Revolução, justapôs-se um outro Kant metafísico, readaptado pela escritora Madame de Staël, durante o Primeiro Império ${ }^{22}$. Tentando conciliar a filosofia experimental e a idealista, ela introduziu $A$ crítica da razão pura com o objetivo de exaltar, junto ao público francês, uma filosofia de entusiasmo e de crença ${ }^{23}$.

Neste modelo de transferência, a interpretação da obra kantiana antecedeu à tradução da mesma, sendo anterior "à construção científica do objeto que ela interpreta[ou]"24. Em outras palavras, o processo hermenêu-

20 Ibid., p.20.

21 ESPAGNE, Michel. En deça du Rhin - L'Allemagne des philosophes français au XIX siècle. Paris: Cerf - Collection Bibliothèque Franco-Allemande, 2005.

22 ESPAGNE, Michel. Les transferts culturels franco-allemands, op. cit, p. 21.

23 Previsto para ser publicado em 1810, seu livro De l'Allemagne, consagrado à obra de Kant, é interditado por Napoleão; em 1813, ele é publicado na cidade de Londres. (Cf. MADAME DE STAËL. De l'Allemagne. Paris: FG - Flammarion, 1968.)

24 ESPAGNE, Michel. Les transferts culturels franco-allemands, p. 21. 
tico visando à integração de um texto desconhecido nos debates de ideias nacionais ocorreu, anteriormente, à tradução tardia das críticas kantianas na França, no início do século XIX.

Ora, o método hermenêutico permite o diálogo entre o sujeito que interpreta e o objeto a ser interpretado. Nessa transferência de um texto, de um livro, de um paradigma, o intérprete desempenha a função de intermediário entre os dois contextos: o de produção e o de recepção.

Como bem mostra essa teoria, a transferência cultural não é determinada unicamente pela preocupação de exportação. "Ao contrário, é a conjuntura do contexto de recepção que decide, em grande parte, o que pode e deve ser importado [... $]^{\prime 25}$. Na maioria das vezes, a importação de ideias e de modelos (intelectuais e estéticos) corresponde aos "ares dos tempos" e aos fenômenos de moda. De fato, são as necessidades específicas do espaço cultural de recepção que determinam e operam a "seleção" (do que pode e deve ser traduzido) pela publicação no estrangeiro. Voltaremos, mais adiante, a tratar desta questão.

Outra possibilidade de análise consiste na apreensão da gênese dos discursos originais. A fim de melhor apreender a maneira como uma obra (intelectual ou artística) se constitui, busca-se conhecer a emergência de uma criação. Inicialmente, o contexto histórico serve de ponto de partida. Em que condições históricas, culturais e ideológicas uma obra científica se edifica? Que situações imediatas determinam sua emergência? Conhecer a historicidade de uma obra científica permite entender tanto as assimetrias entre os espaços culturais como seus sistemas de referências. Como evitar os anacronismos, as ideias fora do lugar, as inevitáveis defasagens, inerentes ao processo de deslocamento de conceitos e de ideias?

Baseados, inicialmente, no método comparativo, os estudos das transferências culturais abandonaram esse "quadro epistemológico da historiografia nacional", abrindo-se, já em meados dos anos 1990, em direção à ideia de cruzamentos, de imbricações, de mestiçagens. Nos Estados Unidos, esta orientação insere-se na "connected history"; na França, na "histoire croisée" ${ }^{26}$, teorizada por Michaël Werner.

25 Ibid., p. 23.

26 WERNER, Michaël; ZIMMERMANN, Bénédicte. Penser l'histoire croisée: entre empirie et réflexivité. Annales H-SS, 58 année, n. 1 (janvier/février), 2003. 
Aos olhos de Michel Espagne, a comparação, um princípio indispensável ao estudo de duas áreas culturais, revelou-se, no entanto, insuficiente para enfatizar os mecanismos de aculturação e de transferência. Se ela é eficaz para opor os grupos sociais entre si, enfatizando mais as divergências do que as convergências, a comparação não cessa de reforçar as clivagens nacionais, impossibilitando a abordagem de uma historiografia transnacional.

"As comparações sempre se operam de um ponto de vista nacional. [...] A tarefa do historiador deveria, sobretudo, consistir em analisar os momentos estrangeiros no processo de constituição de uma nação"27. Acentuando, sobretudo, as diferenças e, em escala menor, as semelhanças, o enfoque comparativo parece restringir o conhecimento das formações culturais, historicamente constituídas. Em outras palavras, a comparação tende a privilegiar a sincronia, enquanto que o cruzamento situa-se numa perspectiva diacrônica, pressupondo um processo que se desenrola no tempo ${ }^{28}$. Embora, o comparatismo e os cruzamentos possam ser utilizados simultaneamente, uma demonstração de suas virtudes e/ou de suas limitações ultrapassaria os limites deste artigo.

Essas considerações acima conduzem o pesquisador a formular algumas questões voltadas à prática de suas pesquisas:

A primeira: Forjadas no quadro das relações franco-alemãs, no século XIX, a teoria e a metodologia das transferências culturais poderiam, efetivamente, ser transplantadas a outras formas de inter-relações culturais e a outros momentos históricos? As investigações recentes em diversas áreas (literatura comparada e estudos culturais), pelo momento, parecem confirmar esta hipótese.

A segunda: $\mathrm{O}$ estudo das inter-relações entre os espaços culturais não imporia um maior conhecimento de determinados métodos (o hermenêutico) e áreas (linguística, línguas estrangeiras)?

A terceira: o método das "transferências culturais" não constituiria um instrumento crítico indispensável à apreensão de uma história intelectual? Ora, parece-me que o valor heurístico deste método consiste em mostrar a irredutibilidade das ideias e dos conhecimentos a áreas espaciais

27 ESPAGNE, Michel. Sur les limites du comparatisme em histoire culturelle. Genèse, v. 17, 1994, p. 120.

28 Cf. WERNER, Michaël; ZIMMERMANN, Bénédicte (Orgs.). De la comparaison à l'histoire croisée. Paris: Le Genre Humain - Seuil, 2004. 
restritas. Elaborar uma história intelectual pressupõe pensar as etapas de sua edificação, de sua circularidade, de sua aceitação ou rejeição, a partir dos interesses em jogo em diferentes setores.

\section{A tradução como mediação cultural}

Nesse processo de transferências culturais, a tradução constitui o veículo essencial de passagem de códigos estrangeiros, constituídos pela língua e pela linguagem. Se, tradicionalmente, a tradução é vista como uma transferência normativa de signos de uma língua a outra, ela não se limita a simples transposições linguísticas, mas à apreensão do contexto cultural que motiva uma criação intelectual. Assim, longe de corresponder a uma cópia do original, a tradução, que não pode pretender buscar uma mesma equivalência discursiva ${ }^{29}$, confronta-se à tradicional questão do Mesmo e do Outro. Se traduzir significa interpretar um texto de uma língua inicial e produzir um novo texto em uma língua final, toda tradução, embora buscando a fidelidade idiomática, constitui uma adaptação.

Transformada, nestas últimas décadas, em uma nova área do conhecimento, a tradução elaborou sua própria teoria e metodologia, anexando os "atos de linguagem", a hermenêutica e os estudos culturais. Para além dos problemas linguísticos, conceituais, editoriais e, sobretudo, culturais, a tradução permite, pela sua própria história, "a investigação das passagens entre culturas". Como bem lembra Michel Espagne, foram os tradutores "que operaram a escolha das obras [julgadas essenciais] como dignas de representar no estrangeiro o espírito nacional" ${ }^{10}$.

Se a tradução poética pressupõe uma criação, a científica demanda certo conhecimento. Buscando, então, adotar um meio termo entre o princípio de fidelidade (que não pode ser entendido como literalidade) e o de liberdade, essa modalidade de transferência é fundamental como procedimento comunicacional.

29 ECCO, Humberto. Quase a mesma coisa - experiência da tradução (trad.). São Paulo:

30 ESPAGNE, Michel. Transferts culturels franco-allemands, p. 8. 
Sem tradição de formação e de valorização do ofício de tradutor, o espaço cultural brasileiro revela-se, em grande parte, deficiente. Apesar de tradutores notáveis terem marcado sua época ${ }^{31}$, o ritmo atual da produção editorial demonstra, por um lado, o amadorismo e, por outro lado, o pouco rigor por parte das editoras. Comparando obras originais com as devidas traduções, constata-se, na minha área de conhecimento, não somente deformações de sentidos, mas graves contrassensos ${ }^{32}$.

Ao estudar os fenômenos de transferência (as traduções, as edições e as publicações), a história intelectual, inevitavelmente, se depara com a questão dos limites. Ao lado de problemas técnicos ligados à língua e a discursos, outras questões se colocam ao tradutor, como o contexto, a hermenêutica, a transferência.

Convém lembrar que os cultural studies, reforçando as grades de análises do Mesmo e do Outro, chamaram a atenção para as questões transversais (que revestem vários domínios do conhecimento) em torno da tradução científica. Problemas linguísticos, conceituais, editoriais, mas, sobretudo, comunicacionais (a compreensão da cultura do Outro) aparecem na tradução de textos científicos.

Muitas vezes, neste processo, as deformações iniciam-se a partir das escolhas indevidas dos próprios títulos, pelo conselho editorial. Em termos de transformações "propositais" ou inconscientes, tomemos o exemplo do título em português da obra de François Cusset, intitulada, no original (em francês), French theory e traduzida no Brasil com outro sentido.

Modelo de uma transferência cultural, a expressão "French theory" traduz, literalmente, a deformação do modelo filosófico francês (dos anos 1960/70), nos Estados Unidos dos anos 1980. Intitulado French theoryFoucault, Deleuze \& Cie et les mutations de la vie intellectuelle aux États-Unis ${ }^{33}$, o título transforma-se, na edição brasileira, em: Filosofia francesa

31 Entre eles, Odorico Mendes, tradutor da Ilíada em português, publicado em 1864. Na segunda metade do século XX, destacam-se os irmãos Campos, Décio Pignatari, Ivo Junqueira, Antônio Houaiss e tantos outros.

32 Um exemplo: na introdução do livro de François Dosse, A história (tradução de Maria Elena Ortiz Assumpçâo), publicado pela Editora EDUSC, 2003, na página 9, a palavra "quatre-vingt" (80) é traduzida por "quarenta". Este erro altera completamente o sentido da frase "A reviravolta crítica dos Annales, no final dos anos quarenta, atesta esta grande "conversão pragmática"”.

33 Paris: Éditions La Découverte, 2003 e 2005. 
- a influência de Foucault, Derrida, Deleuze \& Cia. ${ }^{34}$. Ora, a substituição de "French theory" por "filosofia francesa" altera completamente o significado deste fenômeno de transferência cultural. Com efeito, o título original exprime, admiravelmente, uma invenção americana, ou seja, um caso de deformação, um exemplo típico de uma transferência filosófica.

A expressão "French theory" veio a designar o modelo intelectual americano, em vigor a partir dos anos 1980, também chamado de "pós-estruturalista": uma combinação do desconstrutivismo francês e das subculturas americanas. Assim, "teoria francesa" ("French theory") traduz uma forma de imbricação intercultural, um deslocamento de modelo, uma transposição filosófica, uma readaptação política (o "politicamente correto") e acadêmica (a apropriação pelos departamentos de literatura dos campi americanos da filosofia francesa dos anos 60/70).

Interrogando a razão de tal defasagem na história intelectual transatlântica - a entrada tardia destes pensadores nos Estados Unidos, após a perda de hegemonia dos mesmos na França -, François Cusset revela suas indevidas apropriações por parte, igualmente, da indústria cultural americana:

A análise de um fenômeno de transferência intelectual, principalmente, universitária, nas condições de isolamento da universidade nos Estados Unidos, não impede, de fato, que ela vá buscar seus curiosos avatares junto aos galeristas nova-iorquinos ou junto aos roteiristas californianos, nos romans à clé ou mesmo no uso impróprio, no todo poderoso Michael Crichton, de uma vaga referência a Baudrillard e a Virilio para denunciar a "dissolução mental" e a tecnologia que nos desumaniza $^{35}$.

Publicando a obra French history em 2003 (primeira edição), François Cusset apresenta ao público francês um fenômeno transatlântico de transformação e de imbricação cultural. Trata-se, de fato, de um estudo sobre

34 Porto Alegre: Artmed, 2008.

35 SANDBERG, Jared. PC Forum Attendees Hear Fighting Words on High Technology. Wall Street Journal, 26 march, 1997. Citado por CUSSET, François. Filosofia francesa - a influência de Foucault, Derrida, Deleuze \& Cia. (trad. Fátima Murad). Porto Alegre: Artmed, 2008. 
a recepção dos pensadores franceses, dos anos 1960/70, nos Estados Unidos, a partir dos anos 1980. Autêntica criação americana, a "French theory", misto de radicalismo político, de movimento intelectual e de contracultura, ultrapassa os campi universitários para investir outros espaços culturais.

“Esta 'invenção' americana da 'teoria francesa' representa menos o resultado de um fenômeno de importação que um dos procedimentos de desvio e de hibridação culturais", afirma François Cusset ${ }^{36}$.

Diríamos o mesmo no que se refere à sua publicação no Brasil. Como explicar a escolha, por parte da editora brasileira, de um título que deforma e desvirtua o referencial em questão? Sabe-se que a capa de um livro é um fenômeno de marketing e um elemento fundamental da lógica editorial. Traduzir "french history" por "filosofia francesa" e "Foucault, Derrida Deleuze \& Cia. e as mutações da vida intelectual nos Estados Unidos" por "a influência de Foucault, Derrida, Deleuze \& Cia.", permite pensar que a editora em questão alterou explicitamente o significado de uma obra para atingir um público mais amplo. A escolha deliberada deste título não demonstraria, com efeito, uma estratégia fundamental de marketing?

\section{Mediadores: indivíduos e grupos}

Veículos sociológicos das transferências culturais, "as ideias, os livros, os comportamentos são transmitidos por indivíduos e, sobretudo, por grupos que atravessam materialmente a fronteira" ${ }^{37}$. Metáfora de ultrapassagem dos limites, seja de um espaço territorial, seja de uma área do conhecimento, a fronteira, na sua dimensão geográfica e simbólica, demanda, nos tempos atuais, outros enfoques e problemáticas. O fenômeno da mundialização, por exemplo, marcado pela instantaneidade e pela interconexão da comunicação, delimita, certamente, novos parâmetros para sua leitura.

No entanto, quando uma teoria, um livro, uma corrente intelectual e artística atravessam os limites de um espaço nacional em direção a um

36 La French theory, métissage transatlantique. Sciences Humaines - Foucault, Derrida, Deleuze - pensées rebelles, numéro spécial 3, mai/juin 2005, p. 10.

37 ESPAGNE, Michel. Transferts culturels, op. cit., p. 27. 
outro, a significação dos mesmos se transforma ${ }^{38}$, como já mencionado. Ora, como precisa Espagne, nem tudo se difere, necessariamente, de um lado e outro da fronteira, "mas uma leve defasagem modifica o lugar do objeto dentro do sistema" 39 .

Portanto, se as análises sobre as importações culturais se atêm à dimensão do nacional (do espaço cultural que as recebe), os enfoques sobre as reciprocidades das relações fornecem, simultaneamente, ocasião para um melhor entendimento dos processos de assimilação e/ou de rejeição por parte deste mesmo espaço. É a conjuntura da recepção que determina o que merece ser importado pelos indivíduos e pelos grupos que transportam, de um lado ao outro de uma "fronteira", elementos de um sistema para o interior de outro sistema.

Como mostram seus autores, desde o século XIX, a categoria social constituída pela intelligentsia foi aquela que transpôs fronteiras e entrecruzou culturas. Escritores, artistas, professores, editores, exilados políticos ou viajantes cosmopolitas serviram de intermediários nesse processo de importação e de exportação cultural. Consequência dos estudos culturais, uma vasta literatura se constituiu, nestas últimas décadas, em torno do objeto "exílio" ", fenômeno de circulação de indivíduos, de ideias e uma das modalidades de transferências culturais. No Brasil Colônia, este fenômeno inscreveu-se no século XVIII, momento em que uma elite constituída por estudantes e poetas atravessou mares em busca de novos ares e de cultura ${ }^{41}$.

Assim, a introdução de um autor, de uma obra ou de uma corrente intelectual e/ou estética estrangeira, dentro de um espaço cultural nacional, se processa por meio da mediação de "atores", individuais e/ou coletivos. Edições, missões, instituições universitárias desempenham, igualmente, a função de intermediários nesse processo de deslocamento semântico e de reelaboração de sentido. Investigar os mecanismos de produção, de difusão (transmissão) e de recepção ${ }^{42}$ significa fazer uso, igualmente, da história intelectual que se ocupa desses mesmos objetos.

38 Ibid., p. 28.

39 Ibid., p. 29.

40 RODRIGUES, Helenice. Exílio. In: ; KOHLER, Heliane (Orgs.). Travessias e cruzamentos culturais, op. cit., p. 40-41.

41 Cf. SCOTTI MUZZI, Eliana. O claro e o turvo - paisagem e cultura em Cláudio Manuel da Costa. In: Ibid.

42 Após um período de avanços significativos na área da mídia e da comunicação, os estudos de recepção enfrentam impasses e questionamentos. Segundo seus especialistas, as insuficiências conceituais 
De que maneira as propriedades específicas desses diferentes "agentes" assinalam seus objetos de produção?

Por sua atividade de mediador intelectual entre a França e a Alemanha, no século XIX, Heinrich Heine constitui um protótipo na história das transferências culturais ${ }^{43}$. Impossibilitado de ingressar, como professor, nas universidades alemãs, esse "homem de letras" abandona suas ambições acadêmicas para se tornar escritor em Paris, após a revolução de 1830. A nova conjuntura ideológica na França se revela favorável às atividades intelectuais germânicas, abrindo possibilidades à entrada da filosofia alemã ${ }^{44}$.

Graças à sua educação cosmopolita - judeu alemão, assimilado à cultura germânica -, Heine é introduzido, ainda jovem, à cultura francesa. "Seu engajamento progressivo em favor das ideias da Revolução francesa e a sua decorrente tomada de consciência política o levam a acreditar que a era das nações está[va] terminada" ${ }^{45}$. Instalado em Paris, desde 1831, ele transita entre domínios distintos; inicialmente, na literatura através da Revue des Deux Mondes, em seguida, na filosofia e nas análises históricas alemãs, tentando, em todos eles, interpretar, segundo o mesmo, a inadequação dos movimentos de ideias (o romantismo, por exemplo) nos dois países.

As polêmicas envolvendo Heine e Victor Cousin, especialista de Hegel na Sorbonne, acusado pelo primeiro de desconhecimento do hegelianismo, sem dúvida atestam a predominância das instituições e dos professores franceses na apropriação das ideias alemãs. As teses de Heine sobre a inadequação dos movimentos de ideias na França e na Alemanha só serão melhor aceitas a partir de suas adaptações tardias.

da análise de recepção atestam seus limites e a necessidade de uma nova abordagem (QUÉRÉ, Louis. Faut-il abandonner l'étude de la réception? Disponível em: $<$ http://www.enssib.fr/autres-sites/reseaux-cnet/79/02quere-pdf $>$ ). No entanto, estes estudos florescem no domínio da literatura comparada (ver: GRÈVE, Claude de. La réception comparée. Perspectivas comparatistes, Paris: Champollion, 1999).

43 Cf. WERNER, Michaël. Heine interprète en France de l'Allemagne intellectuelle. Conflits autour d'un cas modèle de transfert culturel. Romantisme, n. 73 (1991 - III).

44 A partir do Primeiro Império até o período entre guerras, a filosofia alemã foi objeto de constantes processos de assimilação, de adaptação e de transformação por parte da intelligentsia francesa. "De l'Allemagne" de Madame de Staël e sua apropriação da obra de Kant, passando por Victor Cousin e sua interpretação do hegelianismo aos famosos seminários de Alexander Kojève sobre Hegel (na École Pratique des Hautes Études, nos anos 1930), o modelo filosófico alemão entrelaçou-se com a filosofia francesa.

45 WERNER, Michaël. Heine interprète em France de l'Allemagne intellectuelle. Conflits autour d'un cas modèle de transfert culturel. Romantisme, n. 173, 1991. 
Agentes de mediação, os exilados intelectuais, ao longo da história, exerceram a função de passadores entre culturas. Abandonando de maneira forçada e/ou voluntária seus países de origem, esses "imigrantes" desenraizados, enquanto estrangeiros, libertos de contextos nacionais opressivos, confrontaram culturas e produziram ideias ${ }^{46}$.

Um exemplo de mediadora entre espaços nacionais distintos (França e Brasil) pode ser encontrado na experiência de exílio de Suely Rolnik ${ }^{47}$, estudante da Universidade de Vincennes, exilada em Paris em 1970, após ter sido presa e torturada no Brasil por participar dos movimentos políticos de contracultura - a revolução poética. Buscando se reconstruir, Suely Rolnik, ex-aluna de sociologia da USP, retoma seus estudos em filosofia, psicanálise e ciências sociais na França. Graças ao seu encontro inicial com Félix Guattari e Gilles Deleuze, ela estabelece uma relação de amizade com os dois, dando assim origem a futuros intercâmbios intelectuais. Junto com Guattari, ela participa da experiência da clínica La Borde e dos movimentos que terão impactos importantes sobre a psiquiatria dos anos 1970.

"No início", ela afirma, "eu chegava aos cursos de Deleuze sem entender nada em filosofia e em francês, mas alguma coisa nele, na sua voz, na sua atitude, na sua maneira de dizer, tudo isso me fazia sair de suas aulas completamente curada: feliz, revitalizada" 48 .

Traumatizada pela experiência da tortura, ela não suporta escutar a língua de seus torturadores e faz rápidos progressos no aprendizado do francês. Autora com Guattari do livro Micropolíticas - cartografias dos desejos (publicado no Brasil em 1986), Suely Rolnik é, igualmente, uma das tradutoras de Mille Plateaux (v. II, IV), livro escrito por Deleuze e Guattari. Dessa época data também seu encontro, em Paris, com a artista plástica brasileira Lígia Clark. A obra dessa última, "Structuration du moi" é, aliás, objeto de sua tese de doutorado ("troisième cycle"), apresentada na França em 1978. Após mais de oito anos de exílio, Suely Rolnik retorna ao Brasil. Para além da psicanálise, que ensina na PUC de São Paulo, ela se interessa pelos processos de subjetividade como forma de liberação pessoal e de intervenção na realidade, aplicados também à arte contemporânea.

46 Dentre uma vasta literatura sobre o assunto exílio, ver SAÏD, Edward. Reflections on exile and other essays. Cambridge, Massachusetts: Harvard University Press, 2000.

47 Cf. op. cit., p. 41.

48 Entrevista concedida em São Paulo, em 05/05/2005. 
Sua postura existencial e intelectual no exílio, certamente, remete a suas experiências anteriores.

"O exílio", diz ela, "na minha vida, começa antes de eu nascer. Porque meus pais são poloneses, judeus poloneses. Minha mãe veio para o Brasil menina. Meu pai veio dois anos antes da guerra. Eu nasci dois anos depois que eles descobriram que toda minha família tinha morrido no holocausto. Então, eu já nasci com a experiência do exílio".

\section{As referências do sistema de importação de ideias}

O simples interesse de se exportar as ideias não determina, por si só, as transferências culturais. Ao contrário, é a conjuntura do contexto receptor que, em geral, define, em um determinado momento, o que pode e deve ser importado ${ }^{49}$.

Especialista das transferências culturais (franco-alemãs do século XIX), Michel Espagne revela que a primeira recepção da obra de Nietzsche, na França, nos anos 1890, encontra-se intimamente ligada ao contexto intelectual francês marcado, nesse momento preciso, pela perda de vitalidade do pensamento historicista. Crítico feroz deste modelo da história, Nietzsche aparece, aos olhos da intelligentsia francesa, como o intelectual alemão do momento, em fase com o novo debate de ideias nas universidades francesas. Portanto, a apropriação, a assimilação e a importação de um autor e/ou de uma obra estrangeira obedecem, irremediavelmente, a uma lógica interna.

Tanto a história intelectual, que se serve de seus métodos e objetos, como a teoria das transferências culturais, que explicita os procedimentos (de importação, de seleção e de adaptação), fornecem subsídios para uma melhor compreensão dos bens culturais (importados ou exportados). Mesmo não se referindo, necessariamente, a uma perspectiva de relação recíproca entre espaços nacionais, a análise dos fenômenos de exportação e de importação é reveladora da projeção coletiva das imagens e das representações culturais. 
Neste sentido, algumas interrogações sobre os processos de seleção, de adaptação e de importação me parecem pertinentes para uma melhor compreensão do espaço cultural nacional. Essas perguntas derivam da minha afinidade com o espaço cultural francês. Como explicar a inexistência de determinadas publicações estrangeiras, cujos autores, legitimados pelo público brasileiro, já haviam sido objeto de diversas traduções? ${ }^{50}$ Como entender a enorme defasagem, mesmo nos dias atuais, na tradução de uma obra estrangeira? ${ }^{51}$ Que critérios determinam, de fato, o processo de seleção ${ }^{52}$ Além de interesses intelectuais e editoriais, que outros fatores interferem nas escolhas das publicações de obras científicas estrangeiras?

Permitindo entrever diferentes mecanismos de seleção, assimilação e rejeição, os estudos empíricos em história intelectual e nas transferências culturais possibilitam investigar outras questões vinculadas ao fenômeno da importação: as emigrações, as memórias interculturais, as raízes estrangeiras da nação etc. As formas de seleção de modelos (as resistências e as rejeições), operadas pela conjuntura da importação, testemunham as apropriações elaboradas no espaço cultural de recepção. Por que determinadas obras, portanto, fundamentais no espaço cultural de produção, são ignoradas ou rejeitadas por outras tradições nacionais?

As teorias da recepção poderiam, igualmente, contribuir para a resposta a esta pergunta. No entanto, convém lembrar que, em termos da recepção da mídia, seus especialistas vêm constatando as insuficiências da mesma e preconizando a busca de outras modalidades de análise (por exemplo, a hermenêutica) capazes, talvez, de dar conta do processo dinâmico de produção e recepção e da relação intrínseca entre o autor, a obra e o público ${ }^{53}$.

50 Penso, particularmente, em uma obra de Michel Foucault, publicada em colaboração com a historiadora Arlette Farge: Le Désordre des familles: lettres de cachet des archives de la Bastille. Paris: Gallimard, 1982.

51 Uma outra questão: por que uma obra capital, como a de Pierre Bourdieu: La distinction - critique sociale du jugement, Ed. du Minuit, 1979, só foi publicada no Brasil em 2009? Refletindo uma realidade socioeconômica da década de 1970, ela não escapa ao anacronismo, em razão das defasagens temporais.

52 Refiro-me aqui, especificamente, às obras de Pierre Bourdieu. Se, atualmente, a quase totalidade de sua obra encontra-se traduzida no Brasil, como entender a não publicação de dois clássicos: Les héritiers - les étudiants et la culture, escrito em 1964, Ed. de Minuit (em colaboração com Jean-Claude Passeron) e Homo academicus, publicado em 1984 ?

53 QUÉRÉ, Louis. Faut-il abandonner l'étude de la réception? Réseaux, n. 79, CNET, 1996. 
Como explicar, então, a lógica de um mercado editorial que, aparentemente, é o principal responsável pelo processo de seleção? A mundialização do conhecimento não reduziria a separação entre os contextos de exportação e as estruturas de importação? Sem dúvida, a conjuntura intelectual e os interesses comerciais do momento explicam parte desta recusa ou desta aceitação.

Como justificar a inexistência de uma tradução brasileira do último livro de Marc Bloch, L'étrange défaite ${ }^{54}$ ("A estranha derrota"), redigido entre julho e setembro de 1940, logo após o sério revés da "batalha da França? Produzido no momento mesmo em que os acontecimentos se desenrolavam, esta obra se define como uma "expertise histórica", um "testemunho político" e um exame das responsabilidades individuais e coletivas. Aliando diferentes gêneros (historiográfico, biográfico, judiciário etc), esta obra, tida como "reveladora" de uma enquete histórica e jurídica, se divide em três partes: inquérito, processo e condenação ${ }^{55}$. Objeto de várias reedições, L'étrange défaite passou a ser considerada uma obra exemplar: um "lugar da memória", um testemunho do ocorrido, uma "história do tempo presente". A designação pelo autor da expressão "história, ciência da transformação" deve-se, exatamente, a essa análise elaborada no calor dos acontecimentos políticos.

Combinando uma análise histórica (uma "prática científica") e um discurso engajado (uma "prática política") ${ }^{56}$, L'étrange défaite revela sua singularidade, situando-se a meio caminho entre uma "história imediata" e um caso de "expertise histórica". Como se sabe, a história do tempo presente, até muito recentemente, era considerada, fora da França, um gênero histórico menor. Ora, o tempo curto do acontecimento, rejeitado pelos Annales, corrente histórica extremamente admirada pela historiografia brasileira, explica, em parte, o desinteresse, no Brasil, pela obra. Marc Bloch elabora uma crítica pertinente sobre as elites políticas e militares,

54 Antes de entrar na Resistência (em 1943), Marc Bloch confia seu manuscrito a um companheiro desse movimento. Em 1944, ele é fuzilado como resistente pela Gestapo. Seu livro é publicado, em 1946, pela editora Franc-Tireur e reeditado em 1957 (Editora Albin Michel), 1990 e 1992 (pela Gallimard, Folio História).

55 DAMAMME, Dominique. Un cas d'expertise. L'étrange défaite de Marc Bloch. Sociétés Contemporaines, n. 39, 2000.

56 Cf. ibid, p. 95. 
sobre o apolitismo da sociedade francesa, em geral, e de sua geração, em particular. Soma-se a isto a percepção tardia, no Brasil, das mudanças de modelos intelectuais franceses, operadas, portanto, desde meados dos anos 1980 e, consequentemente, explicativas da origem do desparecimento desta corrente historiográfica $^{57}$.

Assim, cada tradição historiográfica nacional se apropria, não sem defasagem cronológica, de proposições oriundas das historiografias ditas centrais. As chamadas "école dos Annales" e a "nouvelle histoire" (que, na verdade, constitui a sua última etapa) migraram tardiamente para o Brasil, pouco antes do início de seu declínio. Razão pela qual a corrente dos Annales perdurou tanto tempo neste país, após ter desaparecido em diferentes partes do mundo. Ora, abandonando a ideia de uma "história total", ambicionada por Marc Bloch, esta corrente historiográfica - baseada em uma história imóvel e serial e, portanto, cada vez mais fragmentada - não se adequava mais às mutações epistemológicas e históricas do momento. Aliás, desde meados dos anos 1980, seus próprios historiadores vinham diagnosticando seu enfraquecimento, em razão, notadamente, da crise das ciências sociais e dos novos modelos epistemológicos, anunciadores de seu próprio desmantelamento.

Objeto das transferências culturais, o fenômeno de exportação de ideias demanda uma abordagem transversal (a apreensão dos espaços culturais respectivos) implicando novos pressupostos metodológicos e teóricos. Transportar os novos contextos epistemológicos e metodológicos, anunciadores do declínio de um modelo intelectual ${ }^{58}$, ajudaria a melhor entender o seu próprio desmantelamento.

Em linhas gerais, este artigo tentou mostrar as premissas e as modalidades de uma área das ciências humanas e sociais que investiga as imbricações e suas mestiçagens, em espaços culturais diversos. Cada um desses espaços apresenta, em um determinado momento histórico, uma identidade cultural acrescida pela cultura do Outro. Essa nova identidade se constitui através de relações mútuas, feitas pelas exportações, impor-

57 Cf. RODRIGUES, Helenice. Novas tendências na historiografia francesa nos anos 80 . Revista Brasileira de História, São Paulo, n. 12, 1986.

58 Cf. BURGUIÉRE, André. L'École des Annales, une histoire intellectuelle. Paris: Odile Jacob, 2006. 
tações, assimilações, deformações etc. Se as transferências de ideias e de modelos ocorrem em termos dissimétricos, neste sentido a tradução só pode ser entendida como uma adaptação de um texto, o anacronismo como uma consequência de um processo, a deformação como um efeito de uma transposição.

\section{Referências}

BERND, Zilá (Org.). Americanidade e transferências culturais. Porto Alegre: Editora Movimento, 2005.

BLOCH, Marc. L'étrange defaite. Paris: Gallimard (Folio Histoire), IV édit., 1992. BOURDIEU, Pierre. Les conditions sociales de la circulation internationale des idées. Actes de la recherche en sciences sociales, n. 145, décembre 2002.

BURGUIÈRE, André. École des Annales, une histoire intellectuelle. Paris: Éd. Odile Jacob, 2006.

CUSSET, François. French theory - Foucault, Derrida, Deleuze \& Cie. et les mutations de 1 avie intellectuelle aux États-Unis. Paris: La Découverte, 2003.

CUSSET, François. Filosofia Francesa - a influência de Foucault, Derrida, Deleuze \&Cia. (trad. Fátima Murad). Porto Alegre: Artmed, 2008.

DAMAMME, Dominique. Un cas d'expertise. L'étrange défaite de Marc Bloch. Sociétés Contemporaines, n. 39, 2000.

DETIENNE, Marcel. Comparer l'incomparable. Paris: Seuil, 2000.

ECCO, Humberto. Quase a mesma coisa - experiência de tradução (trad. Eliana Aguiar). São Paulo: Record, 2007.

ESPAGNE, Michel. Sur les limites du comparatisme en histoire culturelle. Genèses, v. 17, septembre 1994.

. Les transferts culturels franco-allemands. Paris: PUF, 1999.

. En deça du Rhin - L'Allemagne des philosophes français au XIX siècle.

Paris: Cerf, 2005.

; WERNER, Michaël. La construction d'une référence culturelle allemande en France: genèse et histoire (1750-1914). Annales ESC, n. 4, juillet-août 1987. 
GRÈVE, Claude de. La réception comparée. Perspectives Comparatistes. Paris: Champollion, 1999.

JOYEUX, Béatrice. Les transferts culturels, un discours de la méthode (bilan historiographique, perspectives d'application). Hypothèses. Paris: Presses Universitaires de la Sorbonne, 2002.

LÜSEBRINK, Hans-Jürgen; REICHARDT, Rolf. Histoire des concepts et transferts culturels, 1770-1815: note sur une recherche. Genèses, v. 14, 1994.

MOATTI, Claudia. La mobilité des personnes en Méditerranée - de l'antiquité á l'époque moderne. Rome: École Française de Rome, 2004.

QUÉRÉ, Louis. Faut-il abandonner l'étude de la réception? Réseaux, n. 79, CNET, 1996.

RODRIGUES, Helenice. Novas tendências na historiografia francesa nos anos 80 . Revista Brasileira de História, São Paulo, n. 12, 1986.

; KOHLER, Heliane (Orgs.). Travessias e cruzamentos culturais: a mobilidade em questão. Rio de Janeiro: Editora FGV, 2008.

SAÏD, Edward. Reflections on exile and other essays. Cambridge, Massachussetts: Harvard University Press, 2000.

TESTOT, Laurent (Org.). Histoire globale - un nouveau regard sur le monde. Paris: Éditions Sciences Humaines, 2008.

WERNER, Michaël. Heine interprète de l'Allemagne en France. Romantisme, v. 73, 1991 - III.

; ZIMMERMANN, Bénédicte (Orgs.). De la Comparaison á l'Histoire Croisée. Paris: Le Genre Humain - Seuil, 2004.

(Orgs.). Penser l'histoire croisée: entre empirie et réflexivité. Annales H-SS, 58 année, n. 1 (janvier/février), 2003.

Recebido em abril de 2010. Aprovado em abril de 2010. 